\title{
Aspects Regarding the Pharmaceutical Waste Management in Romania
}

\author{
Simona Bungau ${ }^{1}$ (1) , Delia Mirela Tit ${ }^{1}$ (D), Katalin Fodor ${ }^{1}$, Gabriela Cioca ${ }^{2}$, Maricel Agop ${ }^{3,4, *}$, \\ Ciprian Iovan ${ }^{5}$, Delia Carmen Nistor Cseppento ${ }^{6}$, Adrian Bumbu ${ }^{6}$ and Cristiana Bustea ${ }^{5}$ \\ 1 Department of Pharmacy, Faculty of Medicine and Pharmacy, University of Oradea, Oradea 410028, \\ Romania; simonabungau@gmail.com (S.B.); mirela_tit@yahoo.com (D.M.T.); katifodor@yahoo.com (K.F.) \\ 2 Preclinical Department, Faculty of Medicine, Lucian Blaga University of Sibiu, Sibiu 550024, Romania; \\ gabriela.cioca@ulbsibiu.ro \\ 3 Department of Physics, Faculty of Machine Manufacturing and Industrial Management, \\ Gheorghe Asachi Technical University of Iasi, Iasi 700050, Romania \\ 4 Academy of Romanian Scientists, Bucharest 050094, Romania \\ 5 Department of Preclinical Disciplines, Faculty of Medicine and Pharmacy, University of Oradea, \\ Oradea 410028, Romania; dr.iovan@biostandard.ro (C.I.); cristianabustea@yahoo.com (C.B.) \\ 6 Department of Psycho Neuroscience and Recovery, Faculty of Medicine and Pharmacy, University of Oradea, \\ Oradea 410028, Romania; delia_cseppento@yahoo.com (D.C.N.C.); adibumbu@yahoo.com (A.B.) \\ * Correspondence: m.agop@yahoo.com; Tel.: +40-741-991-812
}

Received: 30 June 2018; Accepted: 5 August 2018; Published: 7 August 2018

\begin{abstract}
The issue of drug disposal, as well as the development and implementation of efficient collection strategies, represents an important concern at the highest European level. This research looks into the factors that could have an impact on the efficiency of pharmacies in collecting and disposing the medicinal waste of the population. There were 521 pharmacists from all over the country who filled in a questionnaire on their opinion/attitude related to the system of collecting and disposing the pharmaceutical waste of the population. Of the surveyed pharmacists, $16 \%$ work in pharmacies that do not collect unused/expired drugs from the population, and nearly $33 \%$ of those investigated have refused, at least once, to take the unused medicines from the people. Pharmacists' most important reasons for refusing to collect the pharmaceutical waste were the lack of procedure, incomplete legislation, exceeding the amount contracted with the operators, and high costs. Results show that pharmacies in Romania face several deficiencies in the pharmaceutical waste collection services. The lack of implemented programs has contributed considerably to lower standards of pharmaceutical waste management in Romania. This study is the first research on this topic in Romania, a country where the management of drug-based waste generated by the population is at the beginning. The results shown in this survey can provide a reference point for competent authorities in developing and implementing a take-back program for waste medicine whose efficiency is superior to the existing ones.
\end{abstract}

Keywords: pharmaceutical waste; management; collection schemes; unused drug disposal; pharmacists

\section{Introduction}

An important waste category, whose management is a complex and difficult problem for humanity in the context of global population growth, is represented by medical waste. According to the World Health Organization (WHO), medical waste is defined as "waste generated in the diagnosis, treatment or immunization of humans or animals" [1,2]. As medical waste is potentially dangerous and polluting, the inappropriate handling and disposal of it poses a risk to public health and to the environment $[2,3]$. 
Medication represents the main component of medical waste. Its consumption is steadily increasing due to the increasing number of pathologies to be treated, enhanced access to medical services as well as a more frequent self-medication process. Increased consumption leads to a rapid increase in the amount of medical waste, especially in developing countries [1,4]. Compared to the European average and other countries in the region, the consumption of medicines in Romania is low, with a percentage close to $50 \%$ both for prescription drugs and for over-the-counter (OTC) medicines [5,6].

Medicinal waste, synonymous with pharmaceutical waste and unused or expired medicines includes articles intended to prevent, diagnose, and treat diseases in humans or animals [7,8]. In recent decades, this kind of waste has been extensively studied [8-10]. There are currently more than 3000 active pharmaceutical ingredients (APIs) on the EU market [9] that are authorized, and more than 4000 are available worldwide. Additionally, annual worldwide drug consumption exceeds $1,000,000$ tons [10] and is steadily increasing. It is estimated to reach 4.5 trillion doses in 2020, which is $24 \%$ higher than in 2015, both for prescription-based and OTC medicines [11]. Emerging markets, such as those in China, India, Brazil, and Indonesia, due to increased use, are largely responsible for this change, which means that more than half of the world's population will use more than one dose of medicine per day in 2020 [12].

The medicines reach the environment in various ways, such as inadequate disposal in the sink or toilet, household waste, excretion from the human body (as metabolites or even the base compound), urination/defecation, and by washing them off the skin (creams and ointments) [13]. Due to the fact that sewerage systems are not properly equipped to eliminate medicines and their compounds in an efficient way, they can be released in water courses and then get into the drinking water supply system [14] (Figure 1).

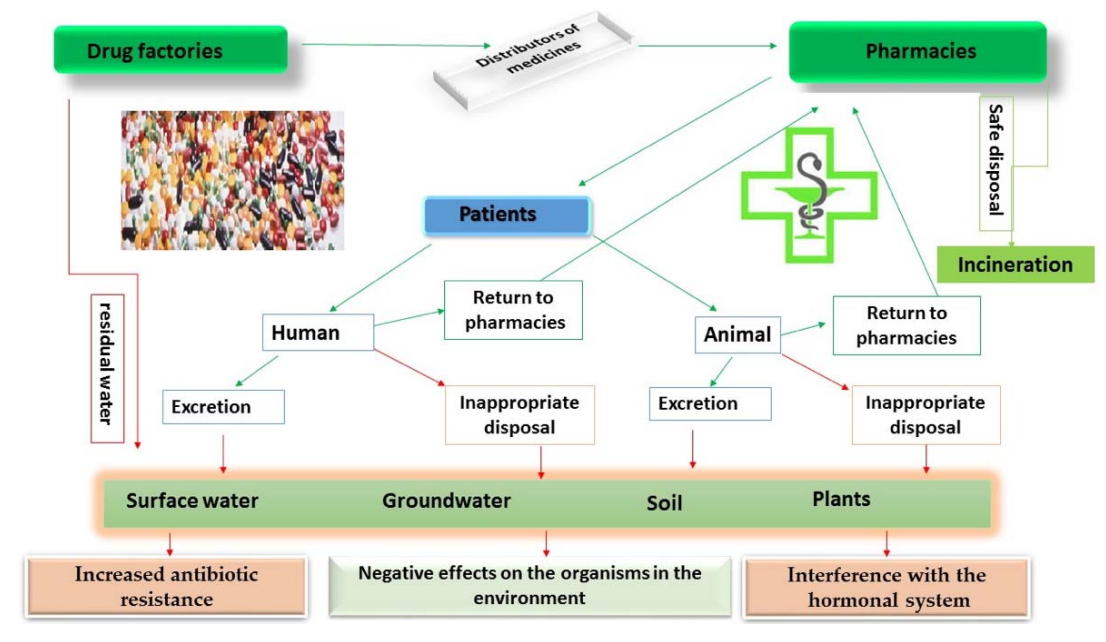

Figure 1. The main ways that drugs contribute to environmental pollution.

Medicines used in the treatment and prevention of diseases in humans and animals are extremely important healthcare tools for society, designed to exhibit specific biological effects in the human or animal body, whose evolution is still under research [15-19]. However, the effects of their interaction, in the environment, with non-target organisms, where they come in the form of metabolites excreted by human or animal organisms that consume them or by the inappropriate disposal of unused medicinal products, are very little understood or even unknown [20]. They reach the environment and pollute the waters and soil, causing negative effects on the organisms in the environment, but also on human health, interfering with the hormonal system and, very importantly, contributing to the increase of antibiotic resistance [21-23]. Negative effects increase with the increasing concentration in active substances. It is extremely important that unused medication be properly managed, given the current 
context of a consistent increase in the use of pharmaceuticals due to aging populations and the development of new drugs [24].

Medical residues discharged in waste (open dumping) reach the soil, and they later gather in the water supplies $[25,26]$. Once they reach the groundwater, the drugs and their decomposition derivatives can harm the environment and human life [27,28], and disinfection [29] and purification [30] is then needed. For example, direct influences of active drugs on the endocrine system determine the feminization of the male fathead minnow, which may lead to an important decrease of the fish population at significant concentrations of this type of substance [28]. Additionally, the chronic exposure to certain estrogens found in contraceptive pills (such as 17-ethinylestradiol) has led to the feminization of male rats, contributing to a significant population reduction [31]. Another class of drugs that has harmful effects on aquatic species is antibiotics. There are studies proving that antibiotics lead to the emergence of new strains of antibiotic-resistant bacteria [32] as well as to the induction of genetic alterations and mutations [33]. Human health issues are still less worrying from this point of view because antibiotics in drinking water are in concentrations significantly lower than the usual recommended doses during treatment. However, another way of exposing humans to the harmful effects of pharmaceuticals is through the consumption of food. Because the long-term summation of any type of chemical in the body has pathological effects [28,31], and pharmaceutical waste is accumulated in the soil and then gets to the plants and animals that are consumed as food, the risks associated with this type of exposure should be taken into account.

Drug treatment at a patient's home often generates pharmaceutical waste. This waste is eliminated in an improper manner worldwide, since people choose the easiest and quickest way to get rid of unnecessary medicines, for example, they throw them in the garbage, down the toilet or in the sink [34-36]. In recent years, the issue related to drug disposal, and to the development and implementation of efficient collection strategies, has been an important concern at the European level and has generated numerous researches [8,37]. In Germany, a pharmaceutical waste take-over system was set up in 1995, and local pharmacies were used as collection points [38]. In 1999, the WHO, through the European Centre for Environment and Health (located in France), initiated an international working group in charge of developing a practical guide that addresses, in particular, issues relating to the management of medical waste in developing economies [16]. In 2004, art. 127b of the European Union Directive on the Creation of a Community Code Relating to Medicinal Products for Human Use (2004/27/EC) stipulated the establishment of collection systems for unwanted drugs at European level. This Directive introduces the obligation of all Member States to have and implement "specific precautions relating to the disposal of unused medicinal products" and appropriate collection systems (Article 127). In article 8c of Directive 2008/105/EC (as amended by Directive 2013/39/EU), there is a provision obliging the European Commission to develop a strategic approach to the pollution of water caused by pharmaceuticals. However, several studies mention that the implementation of these collection systems have an efficiency that varies widely across the EU member states and it is not clear whether all EU countries have implemented these requirements. In the case of Cyprus, Malta, and Bulgaria, there is no information to clarify the existence of such collection systems [39,40].

In Romania, unused pharmaceutical products generated by ambulatory treatments became subject to a legal framework only in 2014 [41]. The existing legislation in Romania (namely Law No. 211/2011 on the waste regime [42] and the Order of the Minister of Health No. 1226/2012 [43]) set up the directions to be followed regarding the management of wastes from medical activities. The National Public Health Institute (a public institution with legal status, subordinated to the Ministry of Health) was appointed as the representative responsible for the management of information on a national scale relating to wastes from medical activities, and it was authorized to approve waste collection on-site, separating it on previously established categories as waste-generating medical activities.

The formulated directions concerned only the specialized units that are the main generators of pharmaceutical waste. Specialized units are considered as follows: Units approved for the sale or distribution of pharmaceuticals (pharmacies, drugstores); units of production, warehousing, 
and storage of medicines and biological products; pharmaceutical research institutes; pre-clinical units of universities and pharmacy colleges; and the National Agency for Medicines and Medical Devices (NAMMD). Another component of pharmaceutical wastes is represented by medicines used in home treatment, in the form of unwanted, expired or unused medicines. Their disposal is established by Order No. 119/2014, which states that: "Expired medicines derived from the population will be submitted to the nearest pharmacy or pharmaceutical point in order to be disposed of and further destroyed by incineration" [41].

However, in the case of medicinal waste taken from the population, the law is not sufficiently explicit. First, it does not clarify very important issues, such as the procedure according to which they are to be taken from patients, namely, handing them over to specialized operators for incineration, and who actually bears the costs of the disposal of the medicines handed over to pharmacies: Manufacturers, pharmacies or local authorities. Practically, costs are supported by pharmacies. In the absence of proper legislation, with well-defined application rules, medications taken from patients follow a complicated and difficult route that "blocks" some of the pharmacy staff.

On the other hand, research studies carried out in Romania on unused drug disposal practices [44-46] have revealed that the methods used by the population were totally inappropriate and inconsistent with legal demands. Thus, both prior to 2014 [44], when the disposal of these wastes was not regulated, and after 2014 [45,46], most of the interviewed persons, irrespective of their age or education, threw them down the toilet or sink, or threw them in the garbage [44,45]. Moreover, until the interview, these people did not even have a problem with eliminating this type of waste in a different way. The results of these studies have shown that the involvement of pharmacists in campaigns that inform and educate citizens can significantly change the way people dispose of pharmaceutical waste. Pharmacists are considered key factors for the functioning and effectiveness of a drug collection system. However, after 4 years of regulation and numerous media campaigns, aimed at raising the awareness among the population about the effects of drug pollution, the collection is still difficult and there are still pharmacies that refuse to take medicines from the population under different pretexts. The latest studies carried out in our country have indicated the presence of a large number of pharmaceutical compounds in the Danube waters [47], important rivers [15], soil [48], and plants [49-52]. This context calls for more in-depth studies on issues related to the management of pharmaceutical waste in Romania. That is the reason why the present research studies the factors that negatively influence the collection of drug wastes from the point of view of the practitioner pharmacists directly involved in this process. Thus, we have applied a questionnaire that investigates their opinion/attitude related to the system of collecting and disposing the pharmaceutical waste of the population.

The objective of this study is to identify the factors that could have an impact on the efficiency of pharmacies in collecting and disposing the medicinal waste of the population in order to develop appropriate strategies and policies. The results obtained from this survey can provide a reference point for competent authorities in developing and implementing a take-back program for waste medicine whose efficiency is superior to the existing ones. Preliminary survey investigations on existing situations can certainly help to identify existing punctual problems at the institutional and national level [8].

\section{Method}

\subsection{Samples}

There were 521 pharmacists from all over the country who filled in a questionnaire on their opinion/attitude related to the system of collecting and disposing the pharmaceutical waste of the population. The questioning was done by phone and on-line (via e-mail and social networks-101 surveys and by telephone-the rest). The topic turned out to be of great interest 
to pharmacists, and the response rate was over $95 \%$ (of the 550 pharmacists questioned, 12 refused to answer, and 17 questionnaires were removed due to incomplete answers).

\subsection{Items Development and Samples}

The method of research used was an Opinion enquiry, based on a questionnaire with 20 items, addressed to pharmacists because, despite legal provisions, there are still pharmacies in Romania that refuse patients/citizens' demand to take-back unused medicines under various pretexts. In Romania, there are currently 7700 pharmacies and 17,850 pharmacists [53]. Each participant in this study works in a different pharmacy, so the sample is representative (calculated with Cochran's simple size formula, modified for small populations [Equations (1) and (2)], with a confidence interval of $0.05(0.44521-0.55479)$ and a confidence level of 99\%) [54].

$$
n_{0}=\frac{Z^{2} p q}{e^{2}}
$$

where the $\mathrm{Z}$-value is found in a $\mathrm{Z}$ table, $e$ is the desired level of precision (i.e., the margin of error), $p$ is the (estimated) proportion of the population with the attribute in question, $q=1-p$, and

$$
n=\frac{n_{0}}{1+\frac{n_{0}-1}{N}}
$$

where $n_{0}$ is Cochran's sample size recommendation, $N$ is the population size, and $n$ is the new, adjusted sample size.

The set of inquiry questions and the variants of the answers were developed following consultations with representatives of the College of Pharmacists from Bihor County (county professional organization of pharmacists, a sub-branch of the College of Pharmacists from Romania, constituting the national level), which is the representative forum of pharmacists for Bihor County. We have carefully analyzed the legislation on the disposal of medicinal waste, good pharmaceutical practice rules, and we have had preliminary discussions with Romanian pharmacists from community pharmacies in the country or from abroad (France, Italy, Hungary, Canada). Items have been thought and developed to identify the factors at the pharmacies that hinder/prevent the collection of drug waste from the population. Questions from the survey were closed and open; the open ones had the role of relaxing the interlocutor in order to get truthful answers (not the answers that the interviewees think that the one who questions them would like to hear). The draft of the questionnaire was pilot-tested [55,56]; it was completed by 80 pharmacists and, as a result, minor wording changes were supported by the original draft.

From an administrative territorial point of view, Romania is organized in 41 counties plus the capital city (Bucharest), which has a status similar to that of a county. The National Register of Pharmacists provides data, by counties, on the names of pharmacists, the professional rank and the workplace. A minimum of 10 and a maximum of 15 pharmacies from each county were chosen randomly, and a representative pharmacist was contacted by phone. This pharmacist was informed about the subject of the questionnaire and its purpose and asked if he wanted to participate in the study. If there was not enough time for the pharmacist to fill in the questionnaire by phone, the questionnaire was sent by email to be completed. Data have been centralized and processed in Excel.

The questionnaire has 4 sections. The first one establishes whether pharmacies collect the drug waste from the population, including the frequency of collection, the amount of waste and the costs involved in the operation. The items in this section were chosen to identify if there are pharmacies that refuse to take back medication from the population, if there is a demand from patients to return the medicines and if the costs involved in the collection have a negative impact. The second part of the collected data related to pharmacists' opinion on the legislation and the procedure for collecting medical waste. This second part aims at identifying the problems in the current system of collecting medical waste from the population, from the point of view of the practitioner directly involved. 
We wanted to see the degree of satisfaction of the pharmacist with the collecting methods applied in pharmacies, if there are situations in which patients' demands are refused, and whether the refusal is related to the current legislative context or determined by other causes. All elected items aimed at identifying the factors that prevented waste collection from the population. In part III, we investigated the way pharmacists tackled the problem of drug pollution and their involvement in educating citizens. The latter part established socio-demographic criteria (Table 1).

Table 1. Questions (items) of the pharmaceutical waste collection, by categories.

\begin{tabular}{|c|c|}
\hline Items & Options for Responding \\
\hline \multicolumn{2}{|l|}{ Collecting waste } \\
\hline $\begin{array}{l}\text { Are you responsible for, or do you share with other persons the } \\
\text { responsibility of, taking decisions regarding the collection of } \\
\text { expired/unused medicines from citizens? }\end{array}$ & Yes-No \\
\hline $\begin{array}{l}\text { Does the pharmaceutical unit you work in collect expired/unused } \\
\text { medicines from citizens for disposal by incineration? }\end{array}$ & Yes-No \\
\hline How often are you asked to take over expired/unused medications? & $\begin{array}{l}\text { Daily, several times/week, once/week, } \\
\text { several times/month, once/month, less }\end{array}$ \\
\hline What amount of medical waste do you deliver annually for incineration? & $25 \mathrm{~kg}, 25 \mathrm{~kg}$ \\
\hline What percentage of this quantity do you estimate comes from the citizens? & $2 \%, 2-5 \%, 5 \%$ \\
\hline Specify the costs of the contract with the collection company & 10 Euro, $10-50$ Euro, 50 Euro \\
\hline $\begin{array}{l}\text { Do you consider that it is normal for you to support the expense of the } \\
\text { disposal of expired/unused medicines taken from the citizens? }\end{array}$ & Yes-No \\
\hline Specify who you think should bear these costs & $\begin{array}{l}\text { Open answer, then categorized by } \\
\text { surveyor into one or more categories }\end{array}$ \\
\hline \multicolumn{2}{|l|}{ Attitude towards the procedure (legislation) } \\
\hline $\begin{array}{l}\text { On a scale from } 1 \text { to } 5 \text {, how do you rate the collection procedure of the } \\
\text { pharmacy you work in? }\end{array}$ & $\begin{array}{l}\text { 1-not at all satisfied, } 5 \text {-extremely } \\
\text { satisfied }\end{array}$ \\
\hline If you are unsatisfied, suggest one or more variants of procedures & $\begin{array}{l}\text { Open answer, then categorized by } \\
\text { surveyor into one or more categories }\end{array}$ \\
\hline Have there been any cases when you refused collection? & Yes-No \\
\hline Specify the main reason for refusal & $\begin{array}{l}\text { Open answer, then categorized by } \\
\text { surveyor into one or more categories }\end{array}$ \\
\hline $\begin{array}{l}\text { How well-informed do you think you are concerning the legislation of } \\
\text { waste disposal? }\end{array}$ & $\begin{array}{l}\text { Not at all informed, little informed, } \\
\text { pretty informed, extremely informed, } \\
\text { I do not know / am not sure }\end{array}$ \\
\hline In your opinion, the legislation is & $\begin{array}{l}\text { Clear and easy to apply, clear but not } \\
\text { applicable, ambiguous, incomplete, } \\
\text { inappropriate, not applicable, I do not } \\
\text { know/I am not sure }\end{array}$ \\
\hline $\begin{array}{l}\text { How useful would it be for you to have a clear application procedure with } \\
\text { full, easy-to-understand and implementable data? }\end{array}$ & $\begin{array}{l}\text { Not at all important, little important, } \\
\text { pretty important, extremely important, I } \\
\text { do not know / I am not sure }\end{array}$ \\
\hline \multicolumn{2}{|l|}{ Attitude towards drug pollution } \\
\hline $\begin{array}{l}\text { How well-informed do you consider you are about the hazards these } \\
\text { wastes represent? }\end{array}$ & $\begin{array}{l}\text { Not at all informed, little informed, } \\
\text { pretty informed, extremely informed, } \\
\text { I do not know/I am not sure }\end{array}$ \\
\hline $\begin{array}{l}\text { How important do you think it is to inform your patients or their families } \\
\text { about how to dispose of unused medicines? }\end{array}$ & $\begin{array}{l}\text { Not at all important, little important, } \\
\text { pretty important, extremely important, } \\
\text { I do not know / I am not sure }\end{array}$ \\
\hline \multicolumn{2}{|l|}{ Socio-demographic characteristics } \\
\hline Do you work in a pharmacy in an urban * or rural ${ }^{* *}$ area? & Urban-rural \\
\hline Do you work in an independent pharmacy or in a pharmacy chain? & Independent-chain \\
\hline Are you a pharmacist or a pharmacy assistant? & Pharmacist-assistant \\
\hline Your age & $35,35-50,50$ \\
\hline
\end{tabular}

\footnotetext{
* urban-in town, ${ }^{* *}$ rural-in the countryside.
} 


\subsection{Methods Used for The Application of The Drug Waste Collection System}

The waste disposal procedure resulting from the specific activity of the pharmacy is clearly established by law, and the pharmacies have contracts with operators specialized in the disposal of hazardous waste [41,42]. Thus, at the pharmacy level, the disposal of expired drugs and other hazardous wastes is done by specialized companies (for a fee) and requires a complete package of services, including counselling on filling in documents required by legislation, specialized and approved packaging, collection, transport by authorized means and disposal by the incineration method. The price of the package is calculated in euros and ranges from 0.8 to 1.5 Euro $/ \mathrm{kg}$, excluding VAT, depending on the quantity and the distance to the ecological station for incineration. Pharmacies are required to conclude an annual contract with specialized firms. Under the contract that costs about 90 euros, pharmacists can hand over $25 \mathrm{~kg}$ of medication for incineration. Any extra quantity is an additional charged.

In the absence of a clear law enforcement procedure or legal framework for products returned by citizens, the pharmacies have their own collection rules. Generally, these are taken on the basis of a protocol by which the patient declares the handing over of the medication for incineration. In the protocol, each returned medicine, the bar code and the quantity (the number of tablets, flacons, ampoules etc.) are specified. The protocol is drawn in 3 copies, one handed over to the patient, one to the pharmacy, and one to the incinerator. Some pharmacies require from the patients the invoice for the returned medicines to prove that they are bought from a pharmacy. All these factors make the collection process difficult and cause some pharmacies to refuse patients' requests.

\section{Results}

\subsection{Socio-Demographic Characteristics}

The lot covers both professional categories, pharmacists and pharmacy assistants $(79.46 \%$, respective $20.54 \%$ ) from independent pharmacies and chain pharmacies (41.47\% respective 58.53 ) across the country. In addition, the lot was constituted from respondents from both urban and rural areas, covering all age categories and all education categories, and the socio-demographic characteristics of the lot are presented extensively in Table 2.

Table 2. Socio-demographic characteristics of the lot.

\begin{tabular}{cccc}
\hline \multirow{2}{*}{ Characteristics } & \multicolumn{2}{c}{ Respondents } \\
\cline { 3 - 4 } & & No. & $\%$ \\
\hline \multirow{2}{*}{ Place of provenance } & Urban & 389 & 74.66 \\
& Rural & 132 & 25.34 \\
\hline \multirow{2}{*}{ Pharmacy type } & Independent pharmacy & 215 & 41.47 \\
& Chain of pharmacies & 306 & 58.53 \\
\hline \multirow{2}{*}{ Professional qualification } & Pharmacist & 414 & 79.46 \\
& Pharmacy assistant & 107 & 20.54 \\
\hline \multirow{2}{*}{ Age groups (years) } & 35 & 287 & 55.09 \\
& $35-50$ & 143 & 27.43 \\
& 50 & 91 & 17.47 \\
\hline
\end{tabular}

\subsection{Collecting Waste}

Data related to the behavior of pharmacies/pharmacists regarding the collection of medical waste are presented in Table 3.

Of the respondents, $75 \%$ reported that they are responsible or share with other persons the responsibility of taking decisions regarding the collection of expired/unused medicines from the citizens. Of the questioned pharmacists, $16 \%$ work in pharmacies that do not collect unused/expired medicines from the population. About $45 \%$ said that, in the pharmacy where they work, less than 
$25 \mathrm{~kg}$ of waste are collected per year. Only $2 \%$ of the pharmacies that collect medical waste are required for this service daily, and nearly $45 \%$ of pharmacies are asked less than once/month to collect expired/unused medication. In Romania, unlike other European countries, there are no statistics indicating the amount of drug waste collected from the population. Data collected in this study indicate that only a small amount of waste is collected from the population. Regarding the costs of this service, an overwhelming majority of over $92 \%$ of those questioned believe that these costs should not be supported by pharmacies. Pharmacists suggested that the costs should be supported by: patients, local authorities, Ministry of Health, Ministry of the Environment, others (NAMMD, Government, manufacturer or supplier, drug-issuing pharmacy, authorized ecological unit).

Table 3. Behavior of pharmacies/pharmacists regarding the collection of medical waste.

\begin{tabular}{|c|c|c|c|}
\hline \multirow{2}{*}{ Items } & & \multicolumn{2}{|c|}{ Respondents } \\
\hline & & No. & $\%$ \\
\hline Responsibility for taking decisions & Yes & 391 & 75.05 \\
\hline $\begin{array}{l}\text { Pharmaceutical unit collects expired/unused } \\
\text { medicines from citizens }\end{array}$ & Yes & 438 & 84.07 \\
\hline \multirow{3}{*}{$\begin{array}{l}\text { Monthly costs of the contract with the collection } \\
\text { company (in euro) }\end{array}$} & 10 & 218 & 41.84 \\
\hline & $10-50$ & 206 & 39.54 \\
\hline & 50 & 97 & 18.62 \\
\hline \multirow{2}{*}{$\begin{array}{l}\text { Amount }(\mathrm{kg}) \text { of medical waste delivered annually } \\
\text { for incineration }\end{array}$} & 25 & 379 & 72.76 \\
\hline & 25 & 142 & 27.26 \\
\hline \multirow{6}{*}{ Request for collection } & Daily & 11 & 2.11 \\
\hline & Several times/week & 17 & 3.26 \\
\hline & Once/week & 83 & 15.93 \\
\hline & Several times/month & 103 & 19.77 \\
\hline & Once/month & 74 & 14.21 \\
\hline & Less & 233 & 44.72 \\
\hline \multirow{4}{*}{ Amount of waste collected from the population } & $2 \%$ & 109 & 20.92 \\
\hline & $2-5 \%$ & 148 & 28.41 \\
\hline & $5 \%$ & 93 & 17.85 \\
\hline & I do not know/I am not sure & 171 & 32.82 \\
\hline $\begin{array}{l}\text { Is it normal or not for pharmacies to support the } \\
\text { cost of removing waste from the population? }\end{array}$ & No & 480 & 92.13 \\
\hline
\end{tabular}

\subsection{Attitude Towards The Procedure (Legislation)}

Over $36 \%$ of the questioned people rated the collection procedure at the pharmacies where they worked with a minimum score (not at all satisfied), and about $14 \%$ said they were extremely satisfied, giving the maximum score. The data gathered in this study indicate the dissatisfaction of a significant percentage of pharmacists. Approximately $36.66 \%$ gave the minimum score (Table 4 ).

Just over $65 \%$ said they were dissatisfied with the current procedure and had at least one suggestion (Table 5).

Nearly $33 \%$ of the investigated pharmacists have refused the take-up of unused medicinal products from citizens at least once. The main reasons are presented in Table 6.

As one can observe, the most important reasons indicated in this study were a lack of procedure, incomplete legislation, exceeding the amount contracted with the operators, and high costs. More than half of the pharmacists (53.6\%) consider themselves sufficiently informed about the waste disposal legislation, only $19.3 \%$ consider themselves highly informed and almost $9 \%$ believe they are little informed or not at all. More than $40 \%$ of the investigated pharmacists consider current legislation incomplete, about $20 \%$ consider the law to be ambiguous, while $12.86 \%$ believe the law is clear and easy to apply. As regards the need for a clear and easy procedure, $73 \%$ of the investigated pharmacists believe that the existence of such a procedure would be extremely important. 
Table 4. Pharmacists' opinion about the procedure.

\begin{tabular}{lccc}
\hline & Items & & \multicolumn{2}{c}{ Respondents } \\
\cline { 2 - 4 } & & No. & $\%$ \\
\hline & 1 & 191 & 36.66 \\
Rating of the collection procedure of the pharmacy & 2 & 112 & 21.50 \\
& 3 & 98 & 18.81 \\
& 4 & 47 & 9.02 \\
Have there been cases when you refused collection? & 5 & 73 & 14.01 \\
\hline & Yes & 171 & 32.82 \\
How well-informed do you think you are regarding & Not at all informed & 12 & 2.30 \\
the legislation on waste disposal? & Little informed & 34 & 6.53 \\
& Pretty informed & 279 & 53.55 \\
& Extremely informed & 101 & 19.39 \\
& I do not know/I am not sure & 95 & 18.23 \\
\hline Waste disposal legislation & Clear and easy to apply & 67 & 12.86 \\
& Clear but not applicable & 49 & 9.40 \\
& Ambiguous & 103 & 19.77 \\
& Incomplete & 224 & 42.99 \\
& Inappropriate & 12 & 2.30 \\
& Not applicable & 32 & 6.14 \\
& I do not know/I am not sure & 34 & 6.53 \\
\hline
\end{tabular}

Table 5. Variants of procedures suggested by pharmacists.

\begin{tabular}{lcr}
\hline \multirow{2}{*}{ If You Are Unsatisfied, Suggest One or More Variants of Procedures $(\mathbf{n}=\mathbf{3 4 2})$} & \multicolumn{2}{c}{ Respondents } \\
\cline { 2 - 3 } & No. & $\%$ \\
\hline $\begin{array}{l}\text { The placement in pharmacies of special containers where citizens can directly } \\
\text { put unused medicines }\end{array}$ & 214 & 62.57 \\
\hline Setting up a service nationwide & 71 & 20.76 \\
\hline Creation of collection centers & 34 & 9.94 \\
\hline $\begin{array}{l}\text { Taking the unused medicines by distribution companies and reselling } \\
\text { them to manufacturers }\end{array}$ & 13 & 3.80 \\
\hline Collective collection from pharmacies & 5 & 1.46 \\
\hline Others & 5 & 1.46 \\
\hline
\end{tabular}

Table 6. The main reasons of pharmacists for refusing collection.

\begin{tabular}{lcc}
\hline \multicolumn{1}{c}{ Specify the Main Reason for Refusal $(\mathbf{n}=\mathbf{1 7 1})$} & \multicolumn{2}{c}{ Respondents } \\
\cline { 2 - 3 } & No. & \% \\
\hline Complicated procedure/lack of time & 38 & 22.22 \\
\hline Company policy & 26 & 15.2 \\
\hline Lack of legislation/way of collecting & 23 & 13.45 \\
\hline Lack of procedures and high costs & 19 & 11.11 \\
\hline The medicines were purchased from other pharmacies & 16 & 9.35 \\
\hline Lack of patient cooperation in completing the necessary forms & 16 & 9.35 \\
\hline Unfortunately, we do not have the storage capacity & 13 & 7.6 \\
\hline $\begin{array}{l}\text { We have far exceeded the amount set by contract per year, and we did not want } \\
\text { to incur additional costs for the pharmacy }\end{array}$ & 13 & 7.6 \\
\hline $\begin{array}{l}\text { Others (they did not have a fiscal receipt, they were inappropriately kept, } \\
\text { they were not from the EU) }\end{array}$ & 7 & 4.1 \\
\hline
\end{tabular}




\subsection{Attitude towards Citizens}

The data obtained from the respondents' self-evaluation, as regards the knowledge of the danger triggered by the reckless disposal of pharmaceutical wastes, show that over $80 \%$ of them consider themselves informed on this topic. Most participants in this study (68.7\%) consider it extremely important to inform patients about the correct way to dispose of unused medications (Table 7).

Table 7. Attitude of pharmacists towards drug pollution.

\begin{tabular}{lccc}
\hline \multirow{2}{*}{ Items } & & \multicolumn{2}{c}{ Respondents } \\
\cline { 2 - 4 } & & No. & $\%$ \\
\hline & Not at all informed & 7 & 1.34 \\
How well-informed do you consider you are about & Little informed & 9 & 17.27 \\
the hazards that these wastes represent? & Pretty informed & 305 & 58.54 \\
& Extremely informed & 123 & 23.61 \\
& I do not know/I am not sure & 77 & 14.78 \\
\hline The importance of informing the population & Not at all important & 6 & 1.15 \\
& Little important & 17 & 3.26 \\
& Pretty important & 133 & 25.53 \\
& Extremely important & 358 & 68.71 \\
& I do not know/I am not sure & 7 & 1.34 \\
\hline
\end{tabular}

The negative potential of pharmaceuticals to pollute the environment raises concerns worldwide, especially as a wide range of medicinal products have been detected in water and soil. By counselling and educating patients, pharmacists can help to reduce the phenomenon of self-medication and excessive medicine consumption [57], and can correct the inadequate behavior of the population regarding the disposal of medical waste.

\section{Discussion}

According to the analysis of the data presented, the Romanian population shows little concern and poor information regarding the disposal/use of pharmaceutical waste [39-42]. For this reason, more information campaigns are necessary to inform and educate the population on the proper storage as well as the appropriate and secure disposal of medical waste in order to reduce the hazard of toxicity and the incidental exposure to medication, mainly concerning children and pets. One of the ways to avoid the abuse of medication [58] at patients' residences is to decrease the quantity of prescribed medicines, especially for acute needs [57]. By means of public education campaigns, citizens' attitudes can be changed significantly. There were 5 randomly selected pharmacies who participated in a study [44] conducted in the north-western part of Romania. At the beginning of the study, all of them had no request from patients for the collection of medical waste. It turned out that, after the implementation of an information and education campaign for the population (for a 6-month period), over $585 \mathrm{~kg}$ (378 $\mathrm{kg}$ in urban areas and $207 \mathrm{~kg}$ in rural areas) of drugs were collected from the population. These medicines were from all therapeutic categories, from OTC to special prescription medications, with a rigorous release regimen, requiring special disposal conditions. Before the campaign, the percentage of the population that returned expired medicine to pharmacies was only $1.1 \%$, and the percentage increased considerably to $87.3 \%$ after the campaign [44]. This fact reveals the huge impact pharmacists have on educating the population concerning the responsible use and disposal of unwanted/expired medicines.

The results of our study showed that the complicated procedure/lack of time, lack of legislation/way of collecting, lack of procedures, and high costs are the main factors that cause some pharmacists to refuse to take unused drugs from the population. These issues, together with the population's low interest, poor information (on how to remove pharmaceutical waste), and increased drug use require specific and comprehensive legislation. Laws, strategies and 
methodologies, dedicated to recovering pharmaceutical waste from the population, must provide for clear responsibilities and information/awareness campaigns for both staff and citizens.

In most European countries, the cost of collecting and disposing medical waste is not borne by pharmacies or, if pharmacies pay for this service, all costs are refunded [59]. Moreover, the imposition of costs to pharmacies in some countries has been associated with a collection rate below the European average [56]. In other European countries, pharmaceutical waste disposal is supported by Local Authorities, Pharmaceutical Industry Groups, Government, or Pharmacies [57]. This study is the first research on this topic in Romania, and its results indicate the need to allocate funds from other sources for the disposal of medical waste. In most European countries, the collection system is a simple one in special containers located in pharmacies, health clinics, household waste disposal sites, street containers, depending on the policy and strategy implemented in each country or region [57]. Most of the suggestions in this study are similar to the collection systems in other countries. One of the most important suggestions was the implementation of a unitary system at the national level. This would increase the efficiency of the take-over service and greatly reduce the current confusion of both pharmacists and patients.

Pharmacists' discontent with the current collection program leads to a clear observation that it is imperative for pharmacists' representatives to be directly involved in the drafting of legislation. Moreover, they have to agree on everything that works in pharmacies, including the collection of the medical waste of the population, if national policies want these methodologies to be operative, effective, and have a satisfactory result.

Several studies have shown that informing and educating patients is essential when it comes to the proper disposal of unused medicines [60-62]. There are no specific data on the number of health professionals (pharmacists, doctors, and nurses) in Romania who advise patients on how to properly dispose of unused medications. The data gathered in this study indicate the availability of the Romanian pharmacists in educating patients, and most of the participants considered that informing patients about the correct way to dispose of unused medications is extremely important. If the population is correctly informed on the appropriate manner of disposing the unused/unwanted medicines (mainly by pharmacists that are in direct contact with the patients), the population is ready to learn and use these disposal procedures of pharmaceutical waste. As the waste generated by the population is considerable, measures to determine a lower consumption of drugs (and, consequently, a lower resultant waste) are imposed.

\section{Conclusions}

The results of our study show that there are several increasing deficiencies of the pharmaceutical waste collection service in pharmacies in Romania. The main shortcomings are the lack of legislation with clear and simple procedures that can be applied to both pharmacists and citizens and the high costs incurred by pharmacies for pharmaceutical and medical waste taken from patients/citizens. Another problem of the pharmaceutical waste take-back system in Romania may be the pharmacists' poor information. In this context, it would be particularly useful to introduce legislative courses in the continuous training system of pharmacists. An efficient strategy for pharmaceutical waste disposal, with a specific and comprehensive legislation with clear responsibilities, and a strong information and awareness campaign for both staff and the general public in Romania are also imperative. The removal of the financial burden of waste disposal from pharmacies, together with raising the attention and awareness of the population can be substantially improved by this service.

On the other hand, simplifying the collection of medical wastes through the implementation of special containers in pharmacies and other sites is desirable. The participation, of all parties concerned in the health system, in educating the population is beneficial and considerably decreases the quantity of pharmaceutical wastes that are inadequately managed and represent a considerable source of environmental pollution. 
Author Contributions: All authors contributed equally to this paper. Conceptualization, S.B. and. M.T.; Data curation, K.F., C.I., D.C.N.C., A.B. and C.B.; Formal analysis, G.C., C.I., D.C.N.C., A.B. and C.B.; Methodology, S.B. and D.M.T.; Supervision, M.A.; Writing—original draft, S.B. and D.M.T.; Writing-review \& editing, K.F., G.C., M.A., C.I., D.C.N.C., A.B. and C.B.

Funding: This research received no external funding.

Conflicts of Interest: The authors declare no conflict of interest.

\section{References}

1. Windfeld, E.S.; Brooks, M.S. Medical waste management-A review. J. Environ. Manag. 2015, 163, 98-108. [CrossRef] [PubMed]

2. Blenkharn, J.I. Healthcare Wastes. Ref. Module Earth Syst. Environ. Sci. 2015. [CrossRef]

3. Rada, E.C.; Istrate, I.A.; Panaitescu, V.; Ragazzi, M.; Cirlioru, T.M.; Apostol, T. A comparison between different scenarios of Romanian municipal solid waste treatment before landfilling. Environ. Eng. Manag. J. 2010, 9, 589-596.

4. Kümmerer, K. Pharmaceuticals in the environment. Annu. Rev. Environ. Res. 2010, 35, 57-75. [CrossRef]

5. Eurostat Self-Reported Use of Non-Prescribed Medicines by Sex, Age and Degree of Urbanization 2017. Available online: http:/ /appsso.eurostat.ec.europa.eu/nui/show.do?wai=true\&dataset=hlth_ehis_md2u (accessed on 9 May 2018).

6. Eurostat Self-Reported Use of Prescribed Medicines by Sex, Age and Degree of Urbanization 2017. Available online: http:/ / appsso.eurostat.ec.europa.eu/nui/show.do?wai=true\&dataset=hlth_ehis_md1u (accessed on 9 May 2018).

7. Daughton, C.G.; Ruhoy, I.S. Reducing the Ecological Footprint of Pharmaceutical Usage: Linkages Between Healthcare Practices and the Environment. In Green and Sustainable Pharmacy; Kümmerer, K., Hempel, M., Eds.; Springer: Berlin/Heidelberg, Germany, 2010; pp. 77-102. ISBN 978-3-642-05199-9.

8. Bataduwaarachchi, V.R.; Weeraratne, C.L. Global medication waste management practices: Challenges and opportunities in developing countries. Int. J. Basic Clin. Pharmacol. 2016, 5, 2290-2294. [CrossRef]

9. Touraud, E.; Roig, B.; Sumpter, J.P.; Coetsier, C. Drug residues and endocrine disruptors in drinking water: Risk for humans? Int. J. Hyg. Environ. Health 2011, 214, 437-441. [CrossRef] [PubMed]

10. KNAPPE Project. Knowledge and Need Assessment on Pharmaceutical Products in Environmental Waters. Final Report. 2008. Available online: Environmentalhealthcollaborative.org/images/KNAPPE_REPORT_ FINAL.pdf (accessed on 29 July 2018).

11. Komilis, D.P. Issues on medical waste management research. Waste Manag. 2016, 48, 1-2. [CrossRef] [PubMed]

12. IMS Institute for Healthcare Informatics. Global Medicines Use in 2020: Outlook and Implications; IMS Institute: Parsippany, NJ, USA, 2015; Available online: https:/ / s3.amazonaws.com/assets.fiercemarkets.net/public/ 005-LifeSciences/imsglobalreport.pdf (accessed on 11 May 2018).

13. Ruhoy, I.S.; Daughton, C.G. Types and quantities of leftover drugs entering the environment via disposal to sewage-Revealed by coroner records. Sci. Total Environ. 2007, 388, 137-148. [CrossRef] [PubMed]

14. Karthikeyan, K.G.; Meyer, M.T. Occurrence of antibiotics in wastewater treatment facilities in Wisconsin, USA. Sci. Total Environ. 2006, 361, 196-207. [CrossRef] [PubMed]

15. Moldovan, Z. Occurrences of pharmaceutical and personal care products as micro pollutants in rivers from Romania. Chemosphere 2006, 64, 1808-1817. [CrossRef] [PubMed]

16. Bashaar, M.; Thawani, V.; Hassali, M.A.; Saleem, F. Disposal practices of unused and expired pharmaceuticals among general public in Kabul. BMC Public Health 2017, 17, 45. [CrossRef]

17. Bacaita, E.S.; Ciobanu, B.C.; Popa, M.; Agop, M.; Desbrieres, J. Phases in the temporal multiscale evolution of the drug release mechanism in IPN-type chitosan based hydrogels. Phys. Chem. Chem. Phys. 2014, 16, 25896-25905. [CrossRef] [PubMed]

18. Radu, V.; Bacaita, S.; Uliniuc, A.; Popa, M.; Susanu, S. Fractal hydrodynamic model for drug release processes from starch based hydrogels. Mater. Plast. 2013, 50, 18-22.

19. Magop, D.; Bacaita, S.; Peptu, C.; Popa, M.; Agop, M. Non-differentiability at mesoscopic scale in drug release processes from polymer microparticles. Mater. Plast. 2012, 49, 101-105. 
20. Kümmerer, K. The presence of pharmaceuticals in the environment due to human use-Present knowledge and future challenges. J. Environ. Manag. 2009, 90, 2354-2366. [CrossRef] [PubMed]

21. Hannah, R.; D'Aco, V.J.; Anderson, P.D.; Buzby, M.E.; Caldowell, D.J.; Cunningham, V.L.; Ericson, J.F.; Johnson, A.C.; Parke, N.J.; Samuelian, J.H.; et al. Exposure assessment of 17 a-ethinylestradiol in surface waters of United States and Europe. Environ. Toxicol. Chem. 2009, 28, 2725-2732. [CrossRef] [PubMed]

22. Caldwell, D.J.; Mastrocco, F.; Hutchinson, T.H.; Länge, R.; Heijerick, D.; Janssen, C.; Anderson, P.D.; Sumpter, J.P. Derivation of an aquatic predicted no-effect concentration for the synthetic hormone, 17 a-ethinylestradiol. Environ. Sci. Technol. 2008, 42, 7046-7054. [CrossRef] [PubMed]

23. Kümmerer, K. Antibiotics in the environment-A review-Part II. Chemosphere 2009, 75, 435-441. [CrossRef] [PubMed]

24. Castensson, S. Pharmaceutical Waste. In Pharmaceuticals in the Environment; Kümmerer, K., Ed.; Springer: Berlin, Germany, 2008; pp. 127-131. ISBN 978-3-540-74664-5.

25. Barnes, K.K.; Christenson, S.C.; Kolpin, D.W.; Focazio, M.J.; Furlong, E.T.; Zaugg, S.D.; Meyer, M.T.; Barber, L.B. Pharmaceuticals and other organic wastewater contaminants within a leachate plume down gradient of a municipal landfill. Groundwater Monit. Rem. 2004, 24, 119-126. [CrossRef]

26. Valero, L.G.; Pajares, E.M.; Sanchez, M.R. The Tax Burden on Wastewater and the Protection of Water Ecosystems in EU Countries. Sustainability 2018, 10, 212. [CrossRef]

27. Khan, U.; Nicell, J. Human health relevance of pharmaceutically active compounds in drinking water. AAPS J. 2015, 17, 558-585. [CrossRef] [PubMed]

28. Bound, J.; Voulvoulis, N. Household disposal of pharmaceuticals as a pathway for aquatic contamination in the United Kingdom. Environ. Health Perspect. 2005, 113, 1705-1711. [CrossRef] [PubMed]

29. Collivignarelli, M.C.; Abba, A.; Benigna, I.; Sorlini, S.; Torretta, V. Overview of the Main Disinfection Processes for Wastewater and Drinking Water Treatment Plants. Sustainability 2018, 10, 86. [CrossRef]

30. Bortolini, M.; Gamberi, M.; Mora, C.; Pilati, F.; Regattieri, A. Design, Prototyping, and Assessment of a Wastewater Closed-Loop Recovery and Purification System. Sustainability 2017, 9, 1938. [CrossRef]

31. Boxall, A.B.A. The environmental side effects of medication. EMBO Rep. 2004, 5, 1110-1166. [CrossRef] [PubMed]

32. Andersson, D.I.; Hughes, D. Antibiotic resistance and its cost: Is it possible to reverse resistance? Nat. Rev. Microbiol. 2010, 88, 260-271. [CrossRef] [PubMed]

33. Isidori, M.; Lavorgna, M.; Nardelli, A.; Pascarella, L.; Parrella, A. Toxic and genotoxic evaluation of six antibiotics on non-target organisms. Sci. Total Environ. 2010, 346, 87-98. [CrossRef] [PubMed]

34. Bronder, E.; Klimpel, A. Unused Drugs Returned to the Pharmacy-New Data. Int. J. Clin. Pharmacol. Ther. 2001, 39, 480-483. [CrossRef] [PubMed]

35. Tong, A.Y.; Peake, B.M.; Braund, R. Disposal Practices for Unused Medications in New Zealand Community Pharmacies. J. Prim. Health Care 2011, 3, 197-203. [PubMed]

36. Kusturica, M.P.; Sabo, A.; Tomic, Z.; Horvat, O.; Solak, Z. Storage and Disposal of Unused Medications: Knowledge, Behavior, and Attitudes among Serbian People. Int. J. Clin. Pharm. 2012, 34, 604-610. [CrossRef] [PubMed]

37. West, L.M.; Diack, L.; Cordina, M.; Stewart, D.A. Systematic Review of the Literature on 'Medication Wastage': An Exploration of Causative Factors and Effect of Interventions. Int. J. Clin. Pharm. 2014, 36, 873-881. [CrossRef] [PubMed]

38. Institute for Social-Ecological Research GmbH. Start: Management Strategies for Pharmaceutical Residues in Drinking Water-Pharmaceuticals for Human Use: Options of Action for Reducing the Contamination of Water Bodies-A Practical Guide. 2008. Available online: http:/ / www.start-project.de/downloads/start_ Practical_guide.pdf (accessed on 6 July 2017).

39. Volmer, G. Disposal of pharmaceutical waste in households-A European Survey. In Green Sustainable Pharmacy; Kümmerer, K., Hempel, M., Eds.; Springer: Berlin/Heidelberg, Germany, 2010; pp. 165-217.

40. Unused Pharmaceuticals Where Do They End Up? Available online: https://noharm-europe.org/sites/ default/files/documents-files/2616/Pharm\%20Report_WEB.pdf (accessed on 16 June 2018).

41. Order No 119/2014 for the Approval of Hygiene and Public Health on the Population's Living Environment, Part I No. 127. Official Gazette of Romania, 21 February 2014. (In Romanian)

42. Law 211/2011 on Waste Regime, Part I No. 220. Official Journal of Romania, 28 March 2014. (In Romanian) 
43. The Order of the Minister of Health No. 1226/03 December 2012 for the approval of the Technical norms on the management of medical waste and of the Methodology of data collection for the national database on waste resulting from medical activities, part I No. 855. Official Gazette of Romania, 18 December 2012.

44. Bungau, S.; Bungau, C.; Tit, D.M. Studies on the Last Stage of Product Lifecycle Management for a Pharmaceutical Product. J. Environ. Prot. Ecol. 2015, 16, 56-62.

45. Tit, D.M.; Bungau, S.; Nistor Cseppento, C.; Copolovici, D.M.; Buhas, C. Disposal of Unused Medicines Resulting from Home Treatment in Romania. J. Environ. Prot. Ecol. 2016, 17, 1425-1433.

46. Bungau, S.; Suciu, R.; Bumbu, A.; Cioca, G.; Tit, D.M. Study on hospital waste management in medical rehabilitation clinical hospital, Baile Felix. J. Environ. Prot. Ecol. 2016, 16, 980-987.

47. Chitescu, C.L.; Kaklamanos, G.; Nicolau, A.I.; Stolker, A.A. High sensitive multi residue analysis of pharmaceuticals and antifungals in surface water using U-HPLC-Q-Exactive Orbitrap HRMS. Application to the Danube river basin on the Romanian territory. Sci. Total Environ. 2015, 532, 501-511. [CrossRef] [PubMed]

48. Fodor, A.; Petrehele, A.; Bungău, S.; Tiţ, D.M. Tetracycline and metabolites in agricultural farmland soil and Petroselinum Crispum var. Neapolitanum roots and leafs. Ann. Univ. Oradea. Fascicle Environ. Prot. 2013, 20, 27-32.

49. Fodor, A.; Petruş-Vancea, A.; Petrehele, A.I.G.; Bungău, S.G. Accumulation Properties and Foliar Limb Effects of Tetracycline and Metabolites in Lactuca sativa L., Eruca sativa L. and Spinacia oleracea L. Nat. Res. Sustain. Dev. 2015, 2015, 57-66.

50. Tăşchină, M.; Copolovici, D.M.; Bungău, S.; Lupitu, A.I.; Copolovici, L.; Iovan, C. The Influence of Residual Acetaminophen on Beans (Phaseolus vulgaris L.) Plants Secondary Metabolites. Farmacia 2017, 65, 709-713.

51. Copolovici, L.; Timis, D.; Taschina, M.; Copolovici, D.; Cioca, G.; Bungau, S. Diclofenac Influence on Photosynthetic Parameters and Volatile Organic Compounds Emission from Phaseolus vulgaris L. Plants. Rev. Chim. Bucharest 2017, 68, 2076-2078.

52. Morosini, C.; Marsoni, M.; Torretta, V.; Conti, F.; Ragazzi, M.; Rada, E.C.; Cioca, G. Factors Affecting Spatial and Temporal Concentration Variability of Pharmaceuticals: Comparison between two WWTPs. Sustainability 2017, 9, 1466. [CrossRef]

53. National Register of Pharmacists. Available online: http://www.colegfarm.ro/registrul-national (accessed on 26 June 2017).

54. Sample Size in Statistics (How to Find It): Excel, Cochran's Formula, General Tips. Available online: http:/ / www.statisticshowto.com/probability-and-statistics/find-sample-size/ (accessed on 30 July 2018).

55. De Vaus, D.A. Surveys in Social Research, 5th ed.; Social Research Today Series; Allcn \& Unwin: Sydney, Australia, 2002; ISBN 1-86508-611-8. Available online: https:/ / epdf.tips/surveys-in-social-research-5thedition-social-research-today-series.html (accessed on 29 July 2018).

56. Social Surveys-An Introduction to Structured Questionnaires and Structured Interviews. Available online: https: / revisesociology.com/2016/01/09/social-surveys-definition-types/ (accessed on 29 July 2018).

57. Bungau, S.; Bungau, C.; Tit, D.M.; Pallag, A. The Influence of Specialized Academic Studies on Self-medication. Rev. Rom. Bioet. 2015, 13, 153-158.

58. Daughton, C.G.; Ruhoy, I.S. Lower-dose Prescribing: Minimizing 'Side Effects' of Pharmaceuticals on Society and the Environment. Sci. Total Environ. 2013, 443, 324-337. [CrossRef] [PubMed]

59. Jonjic, D.; Vitale, K. Issues around household pharmaceutical waste disposal through community pharmacies in Croatia. Int. J. Clin. Pharm. 2014, 36, 556-563. [CrossRef] [PubMed]

60. Kim, S.; Aga, D.S. Potential ecological and human health impacts of antibiotics and antibiotic-resistant bacteria from wastewater treatment plants. J. Toxicol. Environ. Health Part B 2007, 10, 559-573. [CrossRef]

61. Seehusen, D.A.; Edwards, J. Patient practices and beliefs concerning disposal of medicines. J. Am. Board Fam. Med. 2006, 19, 542-547. [CrossRef] [PubMed]

62. Kümmerer, K.; Hempel, M. Green and Sustainable Pharmacy; Part III, Use and Disposal of Pharmaceuticals; Springer: Berlin, Germany, 2010; pp. 179-201. ISBN 978-3-642-05198-2.

(C) 2018 by the authors. Licensee MDPI, Basel, Switzerland. This article is an open access article distributed under the terms and conditions of the Creative Commons Attribution (CC BY) license (http:/ / creativecommons.org/licenses/by/4.0/). 